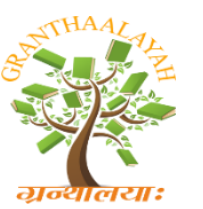

$$
\begin{gathered}
\text { INTERNATIONAL JOURNAL OF RESEARCH } \\
\text { GRANTHAALAYAH } \\
\text { A knowledge Repository }
\end{gathered}
$$

Science

\title{
HUMAN ENERGY UTILIZATION AND EFFECTIVENESS IN SMALL AND MARGINAL FARM HOLDINGS
}

\author{
Tandra Mondal ${ }^{* 1}$, Pranab Kumar Nag ${ }^{1}$ \\ ${ }^{* 1}$ IRDM Faculty Centre, Ramakrishna Mission Vivekananda Educational and Research Institute, \\ Narendrapur, Kolkata-700103, India
}

\begin{abstract}
In India, small and marginal farmers have emerged as a distinct and dominant category. While farm mechanization represents a rapid transformation from traditional to modern methods of farming, it is not uniform across the crops and regions. The level of mechanization, however, remains scattered due to the compulsiveness to the situation dominated by the economic layout of farm holdings, land size, and large-scale deprivation of access to the technology suitable to small holdings. This present contribution elucidates the extent of use tools and machinery among the rice farmers of the state of Wes Bengal, India. Analysis revealed that the total number of man-days involved in paddy cultivation was 120-140 per ha, i.e., 900-1000 man-hours depending upon the availability of labour, tools, and machinery used for the individual operation. Analysis of farm work in small and marginal holdings evolved that over $90 \%$ of the total number of farmers use either tractor or power tiller for land preparation. Use of the animal-drawn country plough is gradually phased out in the study regions. For sowing and transplanting operations are primarily manual methods using hand tools. The study provided an insight of the issues of work methods and practices of the farmworkers in small and marginal farm holdings.
\end{abstract}

Keywords: Farm Mechanization; Small and Marginal Holdings; Work Severity; DrudgeryProneness.

Cite This Article: Tandra Mondal, and Pranab Kumar Nag. (2018). "HUMAN ENERGY UTILIZATION AND EFFECTIVENESS IN SMALL AND MARGINAL FARM HOLDINGS." International Journal of Research - Granthaalayah, 6(11), 163-171. https://doi.org/10.29121/granthaalayah.v6.i11.2018.1114.

\section{Introduction}

Worldwide, the farming sector is dominated by small and marginal holdings (SMH) in the range of $<1$ to 2 ha, i.e., nearly $84 \%$ of the total number of farms (Lowder et al., 2014). Labour intensiveness, family farming, dependence on age-old farming tools and practices make this farming sector more economically vulnerable. The output and efficiency of the SMH are insignificant in comparison to mechanized farms with large farm holdings (Pimentel et al., 2002; Schmitz and Moss, 2016), and therefore, the policymakers often view that farm mechanization is 
the avenue for the emancipation of their backwardness. Farming sector in India employs about 263 million workforces and emerges primarily as a distinct face of SMH category (Government of India, 2017). These farms have meager resources (World Bank, 2003; Dixon et al., 2003) and are maintained by family labors to grow staple food grains (Hazell et al., 2007). In India, this sector acknowledges a gradual transformation from traditional to modern methods of farm practices, yet the farm mechanization lacks uniformity across region and crops (Singh, 2006) due to the compulsiveness of poor economic layout of farm holdings, and large-scale deprivation of technology suitable to SMH (Akdemir, 2013; Van den Berg et al., 2007). The tractor density of northern India (Punjab, Haryana, Uttar Pradesh) is higher than in other states (Singh, 2005). The present scenario of SMH might continue to prevail for decades to come, and therefore, the imperatives are to continually search avenues to alleviate their perceptible risks of uncertainty, potential drudgery proneness and improve in their farm productivity (Mehta et al., 2014). This contribution is elucidating the extent of use of tools and machinery, the human energy spent, man hours involved and work severity related to rice farming activities in SMH.

\section{Methods}

The study was carried out in the farming districts of the state of West Bengal of eastern India, where paddy, potato, vegetables, and jute (totaling about 8 million ha) are the primary crops regarding land utilization and total production (Tewari et al., 2012). West Bengal produces nearly $\sim 15$ million tons of rice, contributing about $15 \%$ of India's total paddy production (Government of India, 2017). Three districts of West Bengal, i.e., Burdwan, Hooghly and South 24 Parganas were selected. Burdwan and Hooghly are the front-runners in producing paddy. The mechanization in the rice cropping is generally low (Paman et al., 2014). The state of West Bengal is dominated by SMH (i.e., $96 \%$ of the total farm families) with an average land holding of 0.77 ha, and cropping intensity of $182 \%$ (Tewari et al., 2012). A single paddy growing season, i.e., monsoon spanning from July to December was covered in the study, and objective data on the cropping activities, including crops time, span, and frequency of each activity starting from land preparation to harvesting, labour requirement, types of machinery and hand tools used were gathered from 400 farmers. Figure 1 illustrates selected farm activities in paddy cultivation. From the record of the number of days involved in each cropping activity per ha land, the total man-days required in the cropping and the extent of human energy expenditure of the activities was estimated, taking into average 7 working hours per day. Hence, the energy requirement per ha of land in paddy cultivation was obtained from the total number of man-hours required, multiplied by the energy value linked to the task. Besides, a questionnaire survey was introduced among the farmworkers to obtain information related to perceived drudgery, accident risks, and other related factors. 

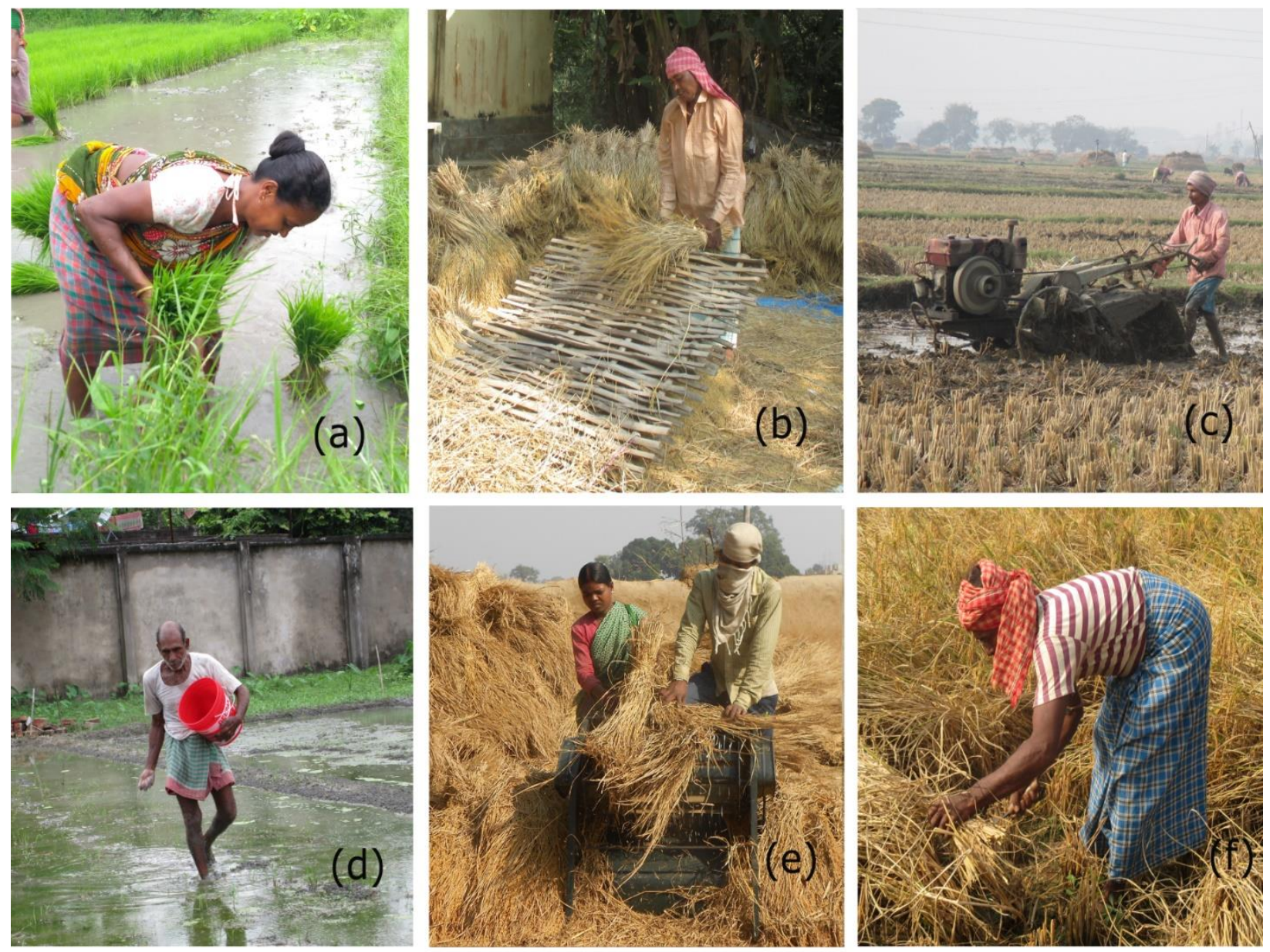

Figure 1: Farming practices (a) manual transplanting; (b) threshing paddy by beating; (c) land preparation with power tiller; (d) fertilizer broadcasting; (e) pedal thresher operation; (f) harvesting paddy with sickle

\section{Results}

The present analysis in SMH indicated a diversity of farming activities, use of hand tools, manually operated devices, and machinery in rice cropping from seedbed preparation to harvesting. The average land holding size of the farmers was 1.13 acre. According to Table 1, for land preparation, $93 \%$ of the total number of farmers use either tractor or power tiller whereas only $7 \%$ of the farmers used the animal-drawn country plough. For sowing and transplanting operation $100 \%$ farmers depend on manual labour and hand tools. The entire irrigation operation was done with the help of power operated machinery, i.e., irrigation pump set. For weeding operation, $63 \%$ of the farmers were using hand tools, and 33\% were using manually operated devices. The entire harvesting operation was carried out with hand tools. For an inter-cultural operation like fertilizer application, $100 \%$ of the farmers were depending on manual broadcasting. Pesticide application was an operation primarily dependent $(93 \%)$ on manually operated devices like knapsack sprayer. Only $4 \%$ of the total number of farmers used the battery operated sprayer. 
Table 1: Distribution of farmers using hand tools/ devices for different farming operations

\begin{tabular}{|c|c|c|c|}
\hline $\begin{array}{l}\text { Farming } \\
\text { operations }\end{array}$ & $\begin{array}{c}\text { Hand Tool } \\
\text { Technology/Mechanical Power } \\
\text { Technology } \\
\end{array}$ & $\begin{array}{c}\begin{array}{c}\text { Distribution of } \\
\text { farmers } \\
\text { (percentage) }\end{array} \\
\end{array}$ & $\begin{array}{c}\text { Man hours } \\
\text { (per ha) }\end{array}$ \\
\hline \multirow[t]{2}{*}{ Land Preparation } & Tractor/ power tiller & 93 & $4.7 / 11.3$ \\
\hline & Animal drawn plough & 7 & 25 \\
\hline $\begin{array}{l}\text { Sowing and } \\
\text { Transplanting }\end{array}$ & Manual & 100 & 222 \\
\hline Irrigation & Power operated machine & 100 & - \\
\hline \multirow[t]{2}{*}{ Weeding } & Hand tools & 67 & 200 \\
\hline & Manually operated device & 33 & 18 \\
\hline $\begin{array}{l}\text { Fertilizer } \\
\text { Application }\end{array}$ & Manual & 100 & 16 \\
\hline \multirow{2}{*}{$\begin{array}{l}\text { Pesticide } \\
\text { Application }\end{array}$} & Manually operated device & 96 & 18 \\
\hline & Power operated machine & 4 & 12 \\
\hline Harvesting & Manual & 100 & 204 \\
\hline \multirow[t]{3}{*}{ Threshing } & Manual & 12 & 288 \\
\hline & Manually operated device & 86 & 218 \\
\hline & Power operated machine & 2 & - \\
\hline \multirow{3}{*}{$\begin{array}{l}\text { Transportation of } \\
\text { crop material }\end{array}$} & Manual & 16 & 324 \\
\hline & Animal drawn cart & 15 & - \\
\hline & Tractor & 69 & 10 \\
\hline
\end{tabular}

The entire harvesting operation of the studied area was carried out by the use of manual labour and hand tools, like sickle and spade. For threshing operation, $86 \%$ of the cases were dependent on manually operated devices like a pedal thresher, and $12 \%$ was performed by the manual pounding of crop material. Only $2 \%$ of the cases, power operated thresher were used to accomplish the threshing operation. Transportation of crop material from the field to threshing ground involved three conditions, i.e., manual transportation with the yoke (16\%), with animal-drawn cart (15\%) and with the tractor $(69 \%)$. The distribution of the man-hours per ha for each activity depicts that activities like harvesting, threshing, and transplanting require most of the man-hours (more than $50 \%$ ), as shown in Table 1 . The use of the tractor, power tiller and country plough for ploughing took an average 4.7 man-hours/ha, 11.3 man-hours/ha, 25 man-hours/ha respectively. The manual sowing and transplanting activity required an average of 222 man-hours/ha to complete the task. Weeding with hand tool took approximately 200 man-hours/ha. On the other hand, weeding with manually operated devices like cono weeder required 18 man-hours/ha to complete the task. Pesticide application with lever operated knapsack sprayer also involved 18 man-hours to spray one hectare of land. Battery operated knapsack sprayer required 12 man-hours/ha to complete the task. Harvesting operation involves around 204 man-hours/ ha when it is carried out with hand tools. Transporting of harvested paddy from the field to the threshing ground also required 324 man-hours per ha when it was done manually. The total number of man-days involved in paddy cultivation was 120-140 per ha, i.e., 900-1000 man-hours depending upon the availability of labour, tools, and machinery used for the individual operation.

Table 2 describes the tool and machinery owning pattern of the farmers under study. About $63 \%$ of the farmers used tractors for land preparation activity by taking it on rent. The average land size 
of the farmers used the tractor for land preparation was about 0.5 ha. On the other, while $35 \%$ of the farmers used power tiller, only $6 \%$ of these farmers own power tiller, and others (29\%) used it on rent. The farmers who owned power tiller are having an average land size of 0.7 ha. Only $6 \%$ of the farmers owned drum seeder, and average land size of the group was 0.8 ha. About $33 \%$ of the farmers owned weeder, and $66 \%$ of them owned an irrigation pump set. $34 \%$ of the total number of farmers took irrigation pump set on rent basis, as and when required. The average land size of the farmers who owned irrigation pump set was 0.5 ha. In the case of lever-operated knapsack sprayer, $61 \%$ of the farmers owned the device while $8 \%$ of them take it on rent. $30 \%$ of the farmers had battery operated knapsack sprayer. $60 \%$ of the farmers had pedal thresher while $30 \%$ use them on rent. The average landholding of the farmers who owned pedal thresher was 0.5 ha, and it is similar to the group who used it on rent.

Table 2: Distribution of farmers own and rent machinery/ devices

\begin{tabular}{|l|l|l|l|}
\hline $\begin{array}{c}\text { Farm machinery/ hand } \\
\text { tool }\end{array}$ & \multicolumn{1}{|c|}{$\begin{array}{c}\text { Distribution of the farmer } \\
\text { (percentage) }\end{array}$} & $\begin{array}{c}\text { Average land size } \\
\text { (ha) }\end{array}$ \\
\hline Tractor & Rent & 63 & 0.5 \\
\hline Power Tiller & Own & 6 & 0.7 \\
\cline { 2 - 4 } & Rent & 29 & 0.4 \\
\hline Country Plough & Own & 46 & 0.4 \\
\hline Drum Seeder & Own & 6 & 0.8 \\
\hline Weeder & Own & 33 & 0.64 \\
\hline Irrigation Pump set & Own & 66 & 0.5 \\
\cline { 2 - 4 } & Rent & 34 & 0.3 \\
\hline \multirow{2}{*}{ Knapsack sprayer } & Own & 61 & 0.5 \\
\cline { 2 - 5 } & Rent & 8 & 0.3 \\
\hline Battery operated sprayer & Own & 30 & 0.7 \\
\hline Pedal thresher & Own & 60 & 0.5 \\
\cline { 2 - 4 } & Rent & 30 & 0.5 \\
\hline Sickle & Own & 100 & 0.45 \\
\hline Spade & Own & 100 & 0.45 \\
\hline Chaff cutter & Own & 18 & 0.64 \\
\hline
\end{tabular}

A comparison of traditional hand tool technology and modern machinery is depicted in Table 3. In several stages of rice farming different machinery, equipment and devices are required and work severity of human labour changes with the use of these machines. The work severity of land preparation with country plough $(0.23-0.46 \mathrm{kWh})$ was moderate to extremely heavy work, but the work severity goes down to light to the moderate category with the introduction of the tractor $(0.17-0.25 \mathrm{kWh})$. Hence the use of tractor in land preparation activities was proved to be a better choice. But the constraint of having relatively smaller plots and economic hardship remains the same. Use of conoweeder (0.43-0.46 kWh), and pedal thresher $(0.35-0.57 \mathrm{kWh})$ also increased the workload of the agriculture labours. Broadcasting fertilizer fell under light to moderate category while pesticide application using knapsack sprayer fell under light to the heavy category. The energy demand was highest, i.e., $0.54-0.7 \mathrm{kWh}$ in case of carrying crop materials from the field. In some activities the energy expenditure was high, but the duration of the work is short for example with threshing paddy with pedal thresher, the energy demand is high, but it completes the task for a shorter period. 
Table 3: Classification of work severity involved in different rice farming activity

\begin{tabular}{|l|l|l|l|l|}
\hline Farming operations & \multicolumn{1}{|c|}{$\begin{array}{c}\text { Hand } \\
\text { Tools/machinery }\end{array}$} & $\begin{array}{c}\text { Energy } \\
\text { Demand } \\
\text { (kWh) }\end{array}$ & $\begin{array}{c}\text { Energy } \\
\text { demand } \\
\text { (kWh/ha) }\end{array}$ & \multicolumn{1}{|c|}{$\begin{array}{c}\text { Work } \\
\text { severity }\end{array}$} \\
\hline Land Preparation & Tractor & $0.17-0.25$ & $0.8-1.3$ & $\begin{array}{l}\text { Light- } \\
\text { moderate }\end{array}$ \\
\cline { 2 - 5 } & Power Tiller & $0.22-0.34$ & $2.5-3.8$ & Moderate \\
\cline { 2 - 6 } & $\begin{array}{l}\text { Animal drawn } \\
\text { plough }\end{array}$ & $0.23-0.47$ & $5.8-11.7$ & $\begin{array}{l}\text { Moderate- } \\
\text { extremely } \\
\text { heavy }\end{array}$ \\
\hline Sowing/Transplanting & Manual & $0.2-0.3$ & $48-52$ & Moderate \\
\hline Weeding & Hand tools & $0.16-0.24$ & $31.8-48.4$ & Light- heavy \\
\cline { 2 - 5 } & Cono weeder & $0.43-0.46$ & $7.6-8.3$ & Heavy \\
\hline Fertilizer Application & Manual & $0.9-0.21$ & $1.5-3.4$ & $\begin{array}{l}\text { Light } \\
\text { moderate }\end{array}$ \\
\hline Pesticide Application & $\begin{array}{l}\text { Liver } \\
\text { Knapsack sprayer }\end{array}$ & $0.05-0.2$ & $0.9-3.5$ & $\begin{array}{l}\text { Light- } \\
\text { moderate }\end{array}$ \\
\hline Harvesting & Manual & $0.1-0.2$ & $23.3-47$ & Light -heavy \\
\hline Threshing & Manual & $0.29-0.36$ & $82-104$ & $\begin{array}{l}\text { Moderate- } \\
\text { heavy }\end{array}$ \\
\cline { 2 - 6 } & Pedal thresher & $0.35-0.57$ & $77-125.2$ & $\begin{array}{l}\text { Heavy- } \\
\text { extremely } \\
\text { heavy }\end{array}$ \\
\hline Transportation of crop \\
material & Manual & $0.54-0.7$ & $175.2-230$ & $\begin{array}{l}\text { Extremely } \\
\text { heavy }\end{array}$ \\
\hline
\end{tabular}

\section{Discussion}

The SMH in India collectively represent $\sim 85 \%$ of the total number of operational holding and $45 \%$ of the total operational area (Government of India, 2017; Ghatak and Roy, 2007). The study indicated that paddy cultivation is a labour intensive task, requiring about 120-140 man-days per ha. The use of machinery was primarily limited to land preparation, using a tractor or power tiller. In most other activities, the farmworkers depended on traditional hand tools and smaller manually operated devices (Yadav et al., 2013; Tewari et al., 2012; Paman et al., 2014). Whereas the use of the tractor for land preparation was found to be a less human energy demanding, in some cases, the work severity increased with the introduction of mechanical tool or devices. Apparently less energy demanding tasks, such as transplanting, harvesting, and sowing required nearly half of the total manhour involved in rice farming. Therefore, the total energy expenditure even for relatively less severe tasks were high per ha of land. There was also a comparable situation in case of the use of pedal thresher, in which the drudgery level was higher as compared to threshing by pounding. Since the man-hours required to complete a task was less in a pedal thresher, the cumulative demand was also less in comparison to manual threshing. Work severity is relatively lower for land preparation activities using the tractor, broadcasting fertilizer and spraying pesticide with knapsack sprayer as these tasks fall in light to moderate category. 
The SMH with limited capital resources is barely capable of introducing machinery (Thapa, 2009; Mottaleb et al., 2016). Despite the introduction of several farm machinery and increase in total farm power availability, the overall coverage of machinery is only about $1 / 4^{\text {th }}$ of the total farms in India, and proportion is much less in case SMH. Large machinery often remains under-utilized due to lack of skill and training (Singh, 2005; Kawasaki, 2010, Foster and Rosenzweig 2010). Presence of bunds in the fragmented land pockets restricts the reach of the tractor to the furthest corners. In remote places, use of the machines becomes a burden to farmers due to the absence of maintenance facility of implements. Undoubtedly, mechanization improves the timeliness and hence increases the productivity and reduces overall human drudgery (Muazu et al., 2014). However, occasional peak energy demands with a certain category of machinery making them risk and accident prone due to physical fatigue of the farm operators (Nag and Nag, 2004). The SMH studied in the selected districts is representative scenario of the small and marginal farmers regarding their work severity and efficiency. The state of farm mechanization analyzed through the growth of power-operated farm machinery over traditional human and animal power operated tools and devices have been emphasized (Hormozi et al. 2012; Fortune and Tawanda, 2013). The conventional method of estimating the state of mechanization has only a marginal consideration to the animate power sources since human energy output cannot be equated to electrical energy. In labor-intensive farming, quantification of energy utilization should primarily be linked to drudgery proneness and human energy expenditure. There are obvious necessities to examine the socio-economic and cultural motivation of the SMH and avenues for work simplification (Mottaleb et al., 2016). There is an apparent demand of need-based and scale specific technology (Mehta et al., 2014) to match the requirements in the prevailing situations, with due account of the economic viability of SMH. That is, scope remains in design and development of efficient small machinery and manually operated devices to match requirements of the farmworkers in small holdings and reduce drudgery and accident proneness.

\section{Conclusion}

The average land holding size of Indian states fall at a dismal level of $1.16 \mathrm{ha}$, and the small and marginal farmers represent nearly $80 \%$ of the total number of farms. Sample representative investigation indicates that the SMH face excruciating challenges of survival and existence due to lack of resources, financial layout and access to appropriate technology. The study evolves a relationship of the total human energy requirement to different farm activities and man power involvement per unit land. Because significant farm power utilization comes from animate sources including human and draught animals, the farm productivity relationship to the state of mechanization in the SMH regarding mechanical energy used and human labour involvement to may be ascertained.

\section{Acknowledgment}

The authors gratefully acknowledge the kind permission of the Vice-Chancellor of the University (Ramakrishna Mission Vivekananda Educational \& Research Institute, Deemed to be University) in undertaking the study.

\section{References}

[1] Akdemir, B. (2013). Agricultural mechanization in Turkey. IERI Procedia, 5, 41-44. 
[2] Dixon, J., K. Taniguchi, and H. Wattenbach. (eds). (2003). Approaches to assessing the impact of globalization on African smallholders: Household and village economy modelling. Proceedings of a working session on Globalization and the African Smallholder Study. Rome: Food and Agriculture Organization.

[3] Fortune, C., \& Tawanda, D. (2013). An Assessment of Agricultural Mechanization Index and Evaluation of Agricultural Productivity of some Fast Track Resettlement Farms in Bindura District of Mashonaland Central Province: Zimbabwe. International Journal of Social Science \& Interdisciplinary Research, 2(7), 62-82.

[4] Foster, A., Rosenzweig, M. (2010b). Barriers to farm profitability in India: mechanization, scale and credit markets. In: Paper Presented at the Conference Agriculture for Development - Revisited, University of California at Berkeley, CA, October 1-2.

[5] Ghatak, M., \& Roy, S. (2007). Land reform and agricultural productivity in India: a review of the evidence. Oxford Review of Economic Policy, 23(2), 251-269.

[6] The government of India. (2017). Agricultural statistics at a glance 2016. Directorate of Economics and Statistics, Department of Agriculture and Cooperation, Ministry of Agriculture. New Delhi, India.

[7] Hazell, P. B., Poulton, C., Wiggins, S., \& Dorward, A. (2007). The Future of small farms for poverty reduction and growth. International Food Policy Research Institute (IFPRI) 2020 Discussion Paper 42, May 2007. Washington D.C.: IFPRI.

[8] Hormozi, M. A., Asoodar, M. A., \& Abdeshahi, A. (2012). Impact of mechanization on technical efficiency: A case study of rice farmers in Iran. Procedia Economics and Finance, 1, 176-185.

[9] Kawasaki, K. (2010). The costs and benefits of land fragmentation of rice farms in Japan. Australian Journal of Agricultural and Resource Economics, 54(4), 509-526.

[10] Lowder, S. K., Skoet, J., \& Raney, T. (2016). The number, size, and distribution of farms, smallholder farms, and family farms worldwide. World Development, 87, 16-29.

[11] Mehta, C. R., Chandel, N. S., \& Senthilkumar, T. (2014). Status, challenges and strategies for farm mechanization in India. Agricultural Mechanization in Asia Africa and Latin America, 45(4), 4350.

[12] Mottaleb, K. A., Krupnik, T. J., \& Erenstein, O. (2016). Factors associated with small-scale agricultural machinery adoption in Bangladesh: Census findings. Journal of rural studies, 46, 155168.

[13] Muazu, A., Yahya, A., Ishak, W. I. W., \& Khairunniza-Bejo, S. (2014). Machinery Utilization and Production Cost of Wetland, Direct Seeding Paddy Cultivation in Malaysia. Agriculture and Agricultural Science Procedia, 2, 361-369.

[14] Nag P. K., Sebastian N. C. \& Mavlankar M. G. (1980). Occupational workload of Indian agricultural workers, Ergonomics, 23:2, 91-102.

[15] Nag, P. K., \& Nag, A. (2004). Drudgery, accidents and injuries in Indian agriculture. Industrial Health, 42(2), 149-162.

[16] Paman, U., Inaba, S., \& Uchida, S. (2014). The mechanization of small-scale rice farming: Labor requirements and costs. Engineering in Agriculture, Environment and Food, 7(3), 122-126.

[17] Pimentel, D., Doughty, R., Carothers, C., Lamberson, S., Bora, N., and Lee, K. ( 2002). Energy inputs in crop production: comparison of developed and developing countries, In Lal, R., Hansen, D., Uphoff, N., and Slack, S.(Eds.), Food Security and Environmental Quality in the Developing World (pp.129-151), Boca Raton: CRC Press.

[18] Schmitz, A., \& Moss, C. B. (2016). Mechanized agriculture: Machine adoption, farm size, and labor displacement. The Journal of Agrobiotechnology Management and Economics. 18(3), 278296.

[19] Singh, G. (2006). Estimation of a mechanisation index and its impact on production and economic factors-A case study in India. Biosystems Engineering, 93(1), 99-106. 
[20] Singh, J. (2005). Scope, progress and constraints of farm mechanization in India. In Tyagi, K., H. Bathla., and Sharma, S. (Eds.), Status of Farm Mechanization in India (48-56). Indian Agricultural Statistics Research Institute: New Delhi.

[21] Tewari, V. K., Kumar, A. A., Kumar, S. P., \& Nare, B. (2012). Farm mechanization status of West Bengal in India. Basic Research Journal of Agricultural Science and Review, 1(6), 139-146.

[22] Thapa, G. (2009). Smallholder farming in transforming economies of Asia and the Pacific challenges and opportunities. In: Discussion Paper Prepared for the Side Event Organized during the Thirty-third Session of IFAD's Governing Council, 18 February 2009. Rome. International Fund for Agricultural Development (IFAD).

[23] Van den Berg, M. M., Hengsdijk, H., Wolf, J., Van Ittersum, M. K., Guanghuo, W., \& Roetter, R. P. (2007). The impact of increasing farm size and mechanization on rural income and rice production in Zhejiang province, China. Agricultural Systems, 94(3), 841-850.

[24] Yadav, S. N., Chandra, R., Khura, T. K., \& Chauhan, N. S. (2013). Energy input-output analysis and mechanization status for cultivation of rice and maize crops in Sikkim. Agricultural Engineering International: CIGR Journal, 15(3), 108-116.

[25] World Bank. (2003). Reaching the rural poor: A renewed strategy for rural development. Washington, DC.

\footnotetext{
*Corresponding author.

E-mail address: tandraghum@ gmail.com
} 